\title{
Wiskott-Aldrich syndrome mutation in two Turkish siblings with X-linked thrombocytopenia
}

\author{
X'e bağlı trombositopenili iki Türk kardeşte Wiskott Aldrich \\ sendromu mutasyonu
}

\author{
Göksel Leblebisatan ${ }^{1}$, Ali Bay², Noriko Mitsuiki ${ }^{3}$, Osamu Ohara ${ }^{3}, K^{2}$ enichi Honma ${ }^{4}$, \\ Kohsuke İmai ${ }^{4}$, Shigeaki Nonoyama ${ }^{4}$ \\ 'Department of Pediatric Hematology, Gaziantep Children's Hospital, Gaziantep, Turkey \\ ${ }^{2}$ Department of Pediatric Hematology, Faculty of Medicine, Gaziantep University, Gaziantep, Turkey \\ ${ }^{3}$ Kazusa NA Research Institute, Japan \\ ${ }^{4}$ National Defense Medical Collage, Japan
}

\begin{abstract}
Wiskott-Aldrich syndrome (WAS) is a clinical condition characterized by thrombocytopenia, eczema, and life-threatening infections. In some cases autoimmunity-related problems and even malignancy might be seen; however, some patients have milder clinical manifestations due to mutations in the same gene family, such as in X-linked thrombocytopenia (XLT), which is generally not associated with serious symptoms of disease, except for thrombocytopenia. Herein we report 2 siblings with chronic thrombocytopenia that were diagnosed with XLT based on a missense mutation in the WASP gene (223G $>$ A, Val75Met). To the best of our knowledge this mutation has not been previously reported in a Turkish patient with XLT. (Turk J Hematol 2011; 28: 139-41)
\end{abstract}

Key words: X-linked thrombocytopenia, Wiskott-Aldrich syndrome, WASP gene

Received: January 25, 2011

Accepted: April 11, 2011

\section{Özet}

Wiskott Aldrich Sendromu (WAS) trombositopeni, egzema ve hayatı tehdit edici enfeksiyonlar ile karakterize klinik durumdur. Bazı vakalarda otoimmünite ile ilgili problemler hatta malign hastalıklar da görülebilmektedir. Bunların yanında aynı gen ailesinden köken alan bazı mutasyonlarda daha hafif klinik seyir görülmektedir. X'e bağlı trombositopeni bunlardan biri olup genellikle trombositopeni dışındaki ciddi semptomları taşımaz. Burada kronik trombositopenisi olan iki erkek kardeş, WASP geninde bir missens mutasyona bağlı X'e bağlı trombositopeni tanısı almaları nedeniyle sunulmuştur. Bu mutasyon bildiğimiz kadarıyla X'e bağlı trombositopeni tanılı Türk hastalarda daha önce bildirilmemiştir. (Turk J Hematol 2011; 28: 139-41)

Anahtar kelimeler: X'e bağlı trombositopeni, Wiskott Aldrich sendromu, WASP geni

Geliş tarihi: 25 Ocak 2011

Kabul tarihi: 11 Nisan 2011

Address for Correspondence: Dr. Göksel Leblebisatan, Department of Pediatric Hematology, Gaziantep Children's Hospital, Gaziantep, Turkey Phone: +90 3423410152 E-mail: gokselleb@yahoo.com 


\section{Introduction}

X-linked thrombocytopenia (XLT) is a congenital disease characterized by small platelets and a clinical spectrum that generally does not include other features of Wiskott-Aldrich syndrome (WAS), such as eczema and recurrent infections. XLT belongs to a disorder group related with the WAS gene family, which is expressed selectively in the hematopoietic stem cell-derived lineage that encodes WAS protein (WASP) functioning in cellular motility, the cytoskeleton, signaling, and apoptosis. According to the literature, the condition is common in Europe and Japan [1]; however, XLT with the detected mutational analysis is not common in Turkey. Herein we present 2 brothers with XLT mutation $(223 \mathrm{G}>\mathrm{A}$, Val75Met), which to the best of our knowledge has not been previously described in a Turkish family.

\section{Case Reports}

\section{Patient 1}

Patient 1 was a 7-year-old boy that has had ecchymosis and mucosal bleeding since the age of 2 years. Laboratory investigation showed moderate thrombocytopenia (platelet count: 20.000-50.000 $\mathrm{mm}^{-3}$ ) and peripheral blood smear showed thrombocytopenia and small platelets (MPV: $5 \mathrm{fL}$ ). The patient's history of eczema, and recurrent or lifethreatening infection, which are observed in the classical WAS clinical picture, was negative. Other findings associated with WAS, including lymphopenia, staphylococcal superinfections, and opportunistic infections, were not observed during followup. The patient was previously followed-up at another clinic as chronic idiopathic thrombocytopenic purpura, and received such treatments as intravenous immunoglobulin therapy until last 2 years. Upon presentation to our hematology clinic at Gaziantep Children's Hospital, physical examination findings were normal, except for generalized petechial lesions. As XLT was considered, he was treated with thrombocyte suspensions when prolonged mucosal bleeding occurred and when the hemoglobin level dropped. No treatments were administered to alter the patient's platelet count. The patient had multiple head traumas that resulted in scalp hematomas, but no intracranial bleeding.

\section{Patient 2}

Patient 2 was the 5-year-old bother of patient 1 and had identical symptoms since the age of 1 year, with severe thrombocytopenia (platelet count: $\cong 10,000 \mathrm{~mm}^{-3}$ ). Patient did not have other findings associated with WAS, such as eczema, and recurrent or life-threatening infections. He received the same treatment as his brother (patient 1). Their father and mother are first cousins.

After the patient's were followed-up by the hematology department because of the familial pattern and microthrombocytes, XLT was suspected. After written informed consent was obtained from the patients' parents, mutational analysis was performed by Kazusa DNA Research Institute and National Defense Medical Collage in Japan, according to their published method (2). A missense mutation [WAS: Exon 2, G $\rightarrow \mathrm{A}, \mathrm{V} \rightarrow \mathrm{M} \quad(\mathrm{c} .223 \mathrm{G}>\mathrm{A}$, Val75Met)] was observed at exon 2 after purified genomic DNA samples were amplified with primer pairs designed to span each exon and exon/intron junction; the specific causative mutation was identified via direct sequencing. At the time this report was written the 2 patients were being monitored closely for bleeding and symptoms of infection. They did not require antibiotic prophylaxis or stem cell transplantation, but splenectomy was considered as a treatment to improve their bleeding status by increasing platelet count.

\section{Discussion}

WAS gene-related conditions are divided into 3 clinical groups: WAS, XLT, and X-linked neutropenia $[3,4]$. Whereas mutations that distort WASP expression and result in the classical WAS clinical symptoms, including eczema and life-threatening infections, in addition to microthrombocytopenia, mutations that result in defective WASP production, such as missense mutations, cause the milder phenotype XLT, which has a better prognosis; however, mutation, WASP production, and the genotype-phenotype relationship show individual differences.

The WASP gene encodes WASP, a 502 amino acid protein that plays a critical role actin cytoskeleton organization, signaling, and immune cell function [5]. This protein has multiple functional domains used in actin polymerization, cellular motility, intracellular signaling, and apoptosis [6]. The actin cyto- 
skeleton is active in the basic mechanisms of cell adhesion and migration. Major dynamic rearrangement of the actin cytoskeleton facilitates cell protrusion, retraction, adhesion, and detachment for migration through tissues and endothelial barriers via WASP participation in the transduction of signals from the cell surface to the actin cytoskeleton (7).

A recent study on XLT mutations that included 178 patients from 11 European countries and Japan identified 62 unique mutations located primarily on exon 1 and exon 2-the majority of which were missense mutations. One of the 3 most common mutations is valine at position 75 (Val75Met), as was observed in the presented patients. This mutation was observed in 22 patients from 16 families in 7 countries [1]. A study that included 262 patients from 227 families (including Turkish cases) reported nonsense mutations $950 \mathrm{G}>\mathrm{T}$ at exon 9 and 1124 $\mathrm{C}>\mathrm{T}$ at exon 10 , missense mutations $138 \mathrm{~T}>\mathrm{A}$ at exon $1,290 \mathrm{C}>\mathrm{T}$ at exon $2,1115 \mathrm{C}>\mathrm{A}$ at exon 10 , and $1542 \mathrm{G}>\mathrm{C}$ at exon 12 , as well as 1 splice mutation at exon 10 in the WASP gene of Turkish patients other than the mutation in the presented cases [8]. A novel mutation at exon 4 was also reported in a Turkish patient [9]. The presented cases did not have a novel mutation, but to the best of our knowledge this is the first report of XLT mutation $(223 \mathrm{G}>\mathrm{A}$, Val75Met) in a Turkish family.

Patients with classical WAS require stem cell transplantation, whereas those with milder variants (XLT) may not. Overall survival among German XLT patients was reported to be excellent, though some exhibited features of WAS, including mild eczema and infections. Because the genotype-phenotype relationship is not unique, in terms of mutations and WASP production, treatment must be evaluated on an individual basis. Proper treatment is based on clinical suspicion, followed by a correct diagnosis. Treatment options include splenectomy to increase the platelet count; however, it is associated with a high infection rate and cases without an increase in thrombocytes following splenectomy have been reported. Splenectomized patients require life-long antibiotic prophylaxis. Stem cell transplantation must be considered on a patient-by-patient basis, as some XLT patients have excellent survival, where others have significant morbidity and mortality secondary to life threatening bleedings [1].

We presented 2 brothers with XLT and a previously unreported mutation from Turkey in order to emphasize that in patients with chronic thrombocytopenia associated with a low platelet count genetic analysis of WAS is necessary for the differential diagnosis of diseases of chronic thrombocytopenia and for preventing administration of unnecessary treatments.

\section{Conflict of interest statement}

The authors of this paper have no conflicts of interest, including specific financial interests, relationships, and/or affiliations relevant to the subject matter or materials included.

\section{References}

1. Albert MH, Bittner TC, Nonoyama S, Notarangelo LD, Burns S, Imai K, Espanol T, Fasth A, Pellier I, Strauss G, Morio T, Gathmann B, Noordzij JG, Fillat C, Hoenig M, Nathrath M, Meindl A, Pagel P, Wintergerst U, Fischer A, Thrasher AJ, Belohradsky BH, Ochs HD. X-linked thrombocytopenia (XLT) due to WAS mutations: clinical characteristics, long-term outcome, and treatment options. Blood 2010;115:3231-8. [CrossRef]

2. Imai K, Morio T, Zhu Y, Jin Y, Itoh S, Kajiwara M, Yata J, Mizutani S, Ochs HD, Nonoyama S. Clinical course of patients with WASP gene mutations. Blood 2004;103:45664. [CrossRef]

3. Ochs HD, Filipovich AH, Veys P, Cowan MJ, Kapoor N. Wiskott-Aldrich syndrome: diagnosis, clinical and laboratory manifestations, and treatment. Biol Blood Marrow Transplant 2009;15:84-90. [CrossRef]

4. Ochs HD, Thrasher AJ. The Wiskott-Aldrich syndrome. J Allergy Clin Immunol 2006;117:725-38. [CrossRef]

5. Gulácsy V, Freiberger T, Shcherbina A, Pac M, Chernyshova L, Avcin T, Kondratenko I, Kostyuchenko L, Prokofjeva T, Pasic S, Bernatowska E, Kutukculer N, Rascon J, Iagaru N, Mazza C, Tóth B, Erdös M, van der Burg M, Maródi L. The J Project Study Group. Genetic characteristics of eighty-seven patients with the Wiskott-Aldrich syndrome. Mol Immunol 2011;48:788-92. [CrossRef]

6. Rengan R, Ochs HD. Molecular biology of the WiskottAldrich syndrome. Rev Immunogenet 2000;2:243-55.

7. Thrasher AJ. New insights into the biology of WiskottAldrich syndrome (WAS). Hematology Am Soc Hematol Educ Program 2009;132-8. [CrossRef]

8. Jin Y, Mazza C, Christie JR, Giliani S, Fiorini M, Mella P, Gandellini F, Stewart DM, Zhu Q, Nelson DL, Notarangelo LD, Ochs HD. Mutations of the Wiskott-Aldrich Syndrome Protein (WASP): hotspots, effect on transcription, and translation and phenotype/genotype correlation. Blood 2004;104:4010-9. [CrossRef]

9. Doğu F, Ariga T, Ikincioğullari A, Bozdoğan G, Aytekin C, Metin A, Babacan E. A case of Wiskott-Aldrich syndrome with de novo mutation at exon 4. Turk J Pediatr 2006;48:66-8. [CrossRef] 